\title{
Application of Multimedia Technology in Japanese Training
}

\author{
Wu Fan ${ }^{1, a}$, Chen Zhen ${ }^{2, b^{*}}$ \\ ${ }^{1}$ College of Foreign Language, Beihua University, Jilin 132013, China \\ ${ }^{2}$ College of Information Technology and Media, Beihua University, Jilin 132013, China \\ a105429662@qq.com, ${ }^{b} 59975235 @ q q . c o m$
}

\begin{abstract}
Keywords: Multimedia application, Computer-aided teaching, Japanese teaching.
\end{abstract}
\begin{abstract}
With rapid development of computer technique and multimedia technology, the research and practice of computer multimedia teaching increasingly attracts the attention of people. Foreign language teaching is an important part of language teaching. How to make computer multimedia technology play the advantages in foreign language teaching becomes an important topic in rapid development of education in China. The paper mainly studies the characteristics and functions of computer multimedia, application of multimedia to foreign language teaching, superiority and limitation of multimedia teaching compared with traditional foreign language teaching methods, and challenges of multimedia teaching on foreign language teachers.
\end{abstract}

\section{Introduction}

With rapid development of education in China, multimedia technology is widely applied to teaching, which not only promotes the reform of teaching methods and teaching structure, but also improves the change of teaching ideas and teaching theory. In multimedia application, computer assisted instruction, modern foreign language teaching theory and teaching practice goes deeper, and more and more modern education technologies especially multimedia technique are applied to foreign language education. The paper focuses on researching the relationship between multimedia application and foreign language teaching.

\section{Multimedia Teaching and Japanese Teaching}

Foreign language teaching has developed for a long time abroad, and the development has gone through several stages. Until the 1960s, translation method was dominant, and it means that mother tongue is use to explain all materials of foreign language, the inter-translation of mother tongue and foreign language is repeated, and only translating mother tongue into correct foreign language can really master grammatical rules. The most important thing of learning foreign language is to learn grammar, which helps to understand and translate foreign language. Translation not only is teaching means, but also is a teaching objective. The disadvantage is that it only focuses on instruction of language knowledge, ignores cultivation of language skills, exaggerates the function of grammar and mother tongue in foreign language teaching, and only notice grammatical form rather than meaning. And the teaching process of the teaching method is very boring, which not only breaks away from language environment and actual meaning of language, but also only focuses on written examination rather than spoken language.

Foreign language teaching is an interactive process. Achieving ideal teaching effect needs to establish a duplex channel between teachers and students, which makes the students and teachers in the state of active interaction. Multimedia teaching method reflects man-machine interaction and teaching strategy of using computers for teaching activities. Multimedia teaching methods of CAI assisting foreign language teaching include individual coaching pattern that learners propose the required teaching content and the computers react according to procedure, practice and training mode that the computers propose some questions or instances, and require the students to answer, discovery learning mode that learners use inductive inference method to find out the solutions under the guidance of teachers, simulation mode that learners provide real situation and perceptual 
experience, instructional game and control mode that various teaching medias are used to realize automatic teaching. Various medias are interconnected to be interactive, which makes multiple medias interactive and fully plays special roles of medias. For example, language laboratory is generally used for learning and training language from AP, AA, AAD to AV. If the lesson type which is dominant by audition is taught in audio-visual language lab, magic lantern, film and video is used to provide audio-visual materials, the learners hear and translate while hearing, and the difficult key words are prompted on display screen, which may have profound effect.

In professional comprehensive Japanese class, the teachers change the conventional linear teaching method into applying computer multimedia to present teaching content. For example, for Japanese literature course, the introduction of writers and works is an important and difficult part for students. How to make students remember different writers in the same times in short time, and how to organize teaching is very difficult. If multimedia teaching is applied, the photos of writers are collected, and the photos are processed to be serial by using PPT, which not only helps students remember the writers, but also makes the class more interesting. Words, sound and image act on senses of students, which arouses active response of cognitive structure of students and makes students rapidly understand the teaching content. The logic connection, meaning and application of key words accelerates internalization process of language information and improves learning effect. The teachers of reading lesson and literature class use dual control system to play the selected video, $\mathrm{CD}$ and video materials to aid teaching. In classroom, according to the teaching requirements, the teachers flexibly manipulate, and make timely explanation, organize the discussion and make language skill training, which makes classroom teaching lively. Language literacy class uses selected videos and pictures as teaching blueprint. The teachers present teaching outline and demonstrate teaching content on screen to make students experience foreign style customs with the content on screen. The teachers instruct the students to observe and analyze, organize the discussion, and make students summarize cultural characteristics and influence, which fully plays the subjectivity of students.

Computer multimedia technology has wide application prospect in foreign language teaching. Multimedia language teaching environment has great importance for cultivating language ability, application capability and comprehensive quality of students, which makes it an important part in teaching system. Rational construction, development and application of environment directly influences the quality of talents. We should deeply learn modern foreign language education teaching theory and modern education technique theory, research the application of modern education technique to foreign language teaching to improve teaching quality and realize the objective of cultivating high-quality talents.

\section{Advantages and Problems of Multimedia Teaching Compared with Traditional Japanese Teaching Method}

Compared with traditional teaching, the application of multimedia technique to foreign language teaching has evident advantages.

Rich teaching content. Multimedia system can use digital compression technique to store lots of words, figures, images and sound. Especially computer aided teaching can provide teaching materials with rich content and good quality for language teaching.

Multiple sensory stimulation. According to psychological research, the learning effect of perception while multiple senses is better than that of single sense. Using multimedia teaching method with video and pictures shows the real language background and place for learners, which not only provides lively language background for them, but also breaks away from traditional teaching mode, and makes learners active.

Enhancing language communication ability of students. Multimedia technique is interactive, which makes the real-time communication between teachers and students frequent.

It is individualized. By using multimedia computer for teaching, the teachers can operate easily. The teachers can know about the learning progress of students and make individualized teaching without influencing other students. 
Any thing has positive and negative effect, so is multimedia language teaching. The development is restricted by objective and subjective factors. The application of multimedia technique to foreign language teaching should notice the following problems.

While purchasing equipment, the school should emphasize effect. The development of multimedia technique has not been standardized. There are lots of developers of multimedia products, there are complex types, and the functions, performance and price have great difference. And the products of multimedia technique update rapidly. Therefore, the school should focus on effectiveness while purchasing equipment. The school should select the products and software with high quality and stable performance. The after-service sales of manufactures should be considers to eliminate the troubles in application.

The schools should make ends meet and develop steadily. The application of multimedia technique needs to cost educational expenditure. There is no doubt that economic problem restricts the development of multimedia application system. Under the situation that educational expenditure is not enough and some audio-visual educational equipment are expensive, the schools should be practical and develop steadily.

\section{Requirements and Challenges of Multimedia Teaching on Teachers}

The development of multimedia teaching makes traditional teaching which is dominated by teaching change into modern foreign language teaching which is dominated by learning. The relationship of teachers, students and teaching media has great change. The interactive characteristic of multimedia makes teachers not be the center of class, but it doesn't mean that the teachers are not important, and it has higher requirements on teachers.

Firstly, the foreign language teachers should master scientific teaching method and make scientific teaching design. Foreign language teachers should use modern education theory and cognitive theory as guidance, and combine the characteristics and rules of foreign language teaching to make scientific and rational teaching design. It mainly includes teaching aim analysis, situation creation, information resource design, design of negotiated learning and intense training, and evaluation of learning effect. And the teachers need to make a series of design on the media, teaching aim, feedback ways of students and teaching evaluation in teaching process.

Secondly, the foreign language teachers must master computer knowledge. The foreign language teachers not only need to have required professional knowledge, but also must master computer knowledge and application skills of teaching equipment including learning hardware and software knowledge of computers, courseware making and research and development of teaching software.

Lastly, the foreign language teachers should master synchronous specialization of dual learning. The profession of foreign language teachers has the characteristic of learning continuously in interaction of teaching and learning. Teaching feedback is the accumulation of experience, and is the refinement process of foreign language teachers. In addition, foreign language teachers need to accept long-term specialized education and in-service training, which is the fundamental reason of improving foreign language teaching quality, and is the reliable guarantee of making foreign language teachers professional. It means that foreign language teachers must receive synchronous specialization to avoid being eliminated.

\section{Acknowledgements}

This work is supported by the Social Science Research Project of Department of Education of Jilin Province (Grant 2014178).

\section{References}

[1] T. Alva. Proceedings of ISTP Conference on JSCIT.2012.344-348P.

[2] M. Petter. Proceedings of ISTP Conference on JSCIT.2012.578-582P. 
[3] M. Carr. Proceedings of SCCI Conference on CVPR.2011. 508-513P.

[4] P. Lester. Proceedings of MMIS Conference on SSRE.2012. 78-84P.

[5] M. Teferel. Proceedings of ISTP Conference on JSCIT 2013. 2158-2162P.

[6] F. Owen. Proceedings of ISTP Conference on JSCIT.2012. 1577-1581P. 